\title{
ANALISA SIFAT MIKRO DAN MEKANIK PADA PEMBUATAN KOMPOSIT MIKROFIBRIL PET-HDPE
}

\author{
Heru Santoso ${ }^{1, \text { a) }}$, Arif Rachman Hakim ${ }^{1, b)}$ \\ ${ }^{1}$ Balai Teknologi Polimer - Badan Pengkajian \& Penerapan Teknologi \\ Gedung 460 Kawasan Puspiptek Tangerang Selatan Banten

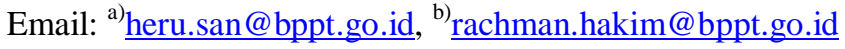

\begin{abstract}
Abstrak
Pencampuran polimer (polymer blending) merupakan salah satu metode yang telah dikembangkan untuk merekayasa material polimer. Dalam penelitian ini telah dilakukan pembuatan komposit mikrofibril PET-HDPE dengan menggunakan alat ekstruder tipe co-rotating twin screw. Proses pembuatan komposit dalam alat ekstruder dengan parameter temperatur $170^{\circ} \mathrm{C} ; 240^{\circ} \mathrm{C} ; 265^{\circ} \mathrm{C}$ dan $280^{\circ} \mathrm{C}$ pada kecepatan putaran $40 \mathrm{rpm}$. Kondisi temperatur penarikan (drawing) pembuatan komposit diatur pada variasi temperatur $75^{\circ} \mathrm{C} ; 80^{\circ} \mathrm{C}$ dan $85^{\circ} \mathrm{C}$ serta kecepatan rasio penarikan $2 ; 3 ; 4$ dan 5 kali lebih cepat dari kecepatan awal. Hasil pembuatan komposit mikrofibril PET-HDPE dilakukan analisis sifat mikro dengan alat SEM (Scanning Electron Microscope) dan sifat mekanik dengan alat UTM (Universal Testing Machine) dan impact charpy. Pada penelitian ini didapatkan nilai kuat tarik tertinggi 24,60 MPa pada kondisi temperatur $85^{\circ} \mathrm{C}$ dengan kecepatan rasio penarikan 2 kali. Kekuatan impak tertinggi komposit PET/HDPE adalah $131.49 \mathrm{MPa}$ pada kondisi temperatur penarikan $85^{\circ} \mathrm{C}$ dan rasio kecepatan penarikan 4 kali. Sedang hasil analisa mikro menggunakan SEM terhadap komposit mikrofibril PETHDPE belum dihasilkan fiber PET yang diharapkan pada komposit. Hal ini kemungkinan disebabkan proses penarikan yang tidak stabil dan temperatur penarikan yang belum tercapai.
\end{abstract}

Kata-kata kunci: Komposit mikrofibril, ekxtruder twin screw, pencampuran polimer PET-HDPE

\begin{abstract}
Polymer blending is one of the methods that have developed to create new polymer materials with different physical properties. This paper aims to investigate of tensile strength, impact strength of microfibril PET-HDPE composites and to obtain PET fiber. Composites were prepared in co-rotating twin screw kneader extruder type ZK 25 E x 36 L/D. The tensile strength, impact Charpy strength from microfibril PET-HDPE and microstructure PET fiber was characterized using Shimadzu AG-X plus 50kN Universal Testing Machine, Resil Impactor CEAST and JEOL JSM 6510 LA Scanning Electron Microscope. Composites were varied at temperature $170^{\circ} \mathrm{C}, 240^{\circ} \mathrm{C}, 265^{\circ} \mathrm{C}$ and $280^{\circ} \mathrm{C}$ and mixing speed was controlled at $40 \mathrm{rpm}$. Drawing temperature was set at $75^{\circ} \mathrm{C}, 80^{\circ} \mathrm{C}, 85^{\circ} \mathrm{C}$, ratio drawing speed at $2 ; 3$; 4 and 5-time initial drawing speed. The results showed that maximum tensile strength is $24.60 \mathrm{MPa}$ on condition $85^{\circ} \mathrm{C}$ with ratio drawing speed 2-time initial drawing speed. The maximum impact Charpy strength is $131.49 \mathrm{MPa}$ on condition $80^{\circ} \mathrm{C}$ with ratio drawing speed 4-time initial drawing speed. The result of microstructure was not obtained PET fiber. In this case, caused by drawing speed was not stable drawing temperature was not reached.
\end{abstract}

Keywords: Microfibril composites, extruder twin screw, polymer blending PET-HDPE 


\section{PENDAHULUAN}

Pencampuran polimer (polymer blending) merupakan salah satu bidang yang penting dalam penelitian polimer karena dapat diperolehnya sifat yang sinergis dan unik dalam pencampuran polimernya. Tujuan dari pembuatan pencampuran polimer adalah untuk menghilangkan atau mengurangi kekurangan yang dimiliki oleh sifat polimer secara individual. Alasan lain yaitu untuk menurunkan harga polimer yang mahal dengan diperolehnya sifat khusus melalui pencampuran polimer yang lebih murah tanpa mengalami kerusakan sifat mekanik yang signifikan. Akan tetapi sebagian besar polimer tidak bisa bercampur pada skala molekuler, entropi pencampuran yang rendah dan tidak ada interaksi antar bahan yang dicampur sehingga dihasilkan pencampuran dengan sifat mekanik yang rendah. Sistem pencampuran polimer heterogen ini dapat ditingkatkan dengan berbagai metode antara lain dengan proses reaktif dan non reaktif. Sebagai contoh, penggunaan kompatibilizer merupakan metode yang sangat efektif untuk meningkatkan interaksi antara polimer dalam campurannya.

Polietilena (PE) merupakan salah satu plastik komoditi yang banyak digunakan dalam aplikasi pengemas dan bahan bangunan. Sedang poly ethylene terepththate PET) adalah jenis plastik engineering (teknik) yang harganya lebih mahal bila dibandingkan dengan plastik komoditi. Aplikasi PET banyak digunakan dalam botol air minum, film dan benang tekstil,

Pencampuran serat immiscible dalam termoplastik semi kristalin untuk menghasilkan komposit mikrofibril (MFC) telah mendapat banyak perhatian dari kalangan peneliti dalam beberapa tahun terakhir ini. Pembentukan serat dari fase terdispersi membutuhkan elongasi partikel fase terdispersi dari pada putusnya. MFC ditandai oleh matriks termoplastik isotropik yang diperkuat oleh fibril dari bahan termoplastik lain (fase terdispersi) yang dihasilkan in situ selama pemrosesan. Jadi mereka berbeda dari komposit konvensional yang dibuat oleh pencampuran komponen konstitutif (matriks dan serat).

Pembuatan komposit berpenguat mikrofibril (microfibrillar reinforced composites : MFC) mencakup tiga langkah dasar seperti ditunjukkan pada GAMBAR 1 yaitu :

- Mixing and Extrusion, yaitu proses ekstrusi campuran secara meleleh dari polimer immiscible yang mempunyai perbedaan temperatur leleh $(\mathrm{Tm})$ yang menghasilkan campuran filamen isotropik dan kontinyu.

- Drawing and Fibrillation : penarikan dalam kondisi dingin untuk mendapatkan orientasi dari kedua fase. Langkah ini menghasilkan orientasi mikrofibril yang tinggi sepanjang arah aksial atau sumbu simetri.

- Post-processing : perlakuan termal pada temperatur antara kedua temperatur leleh (Tm) dari kedua polimer untuk menjamin pembentukan matrik isotropik, sementara masih mepertahankan orientasi fibril yang tinggi.

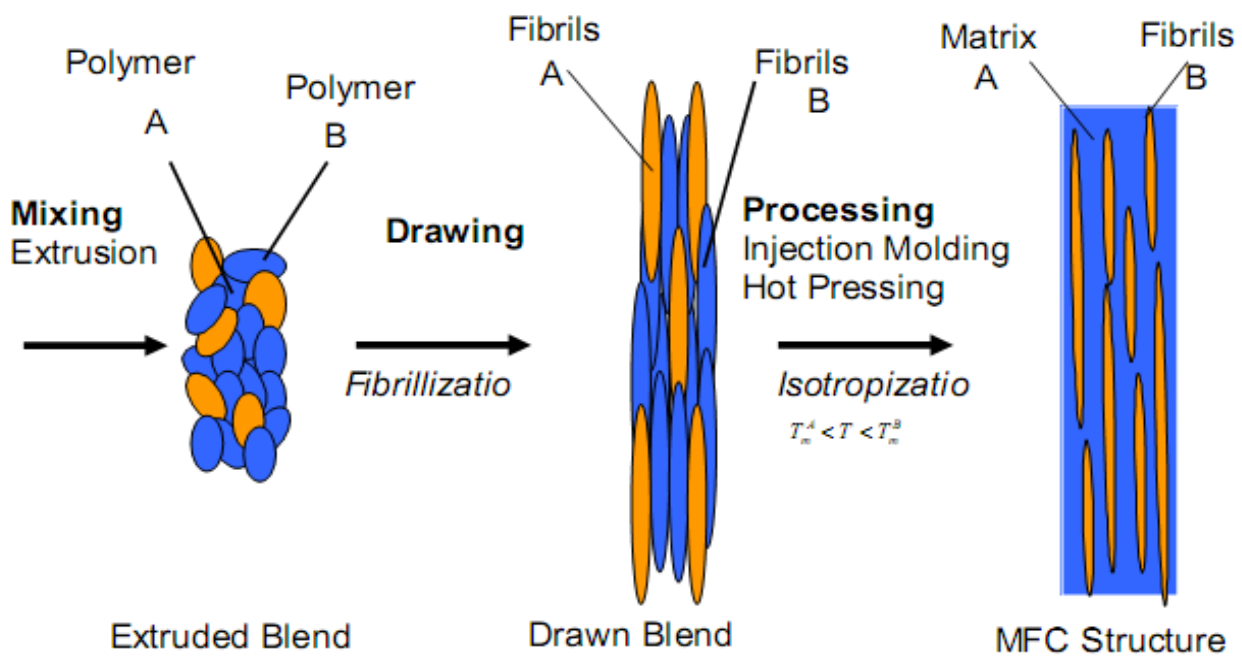

GAMBAR 1. Prinsip dasar pembentukan komposit mikrofibril (MFC) 
Teknologi MFC telah terbukti menjadi metode yang efektif untuk material poliolefin dan PET karena mampu menghasilkan produk dengan sifat yang lebih baik daripada blending secara konvensional. Karingamanna et.al (2010) telah melakukan penelitian MFC dari LLDPE-PET, Maja Kuzmanovic et.al (2016) meneliti pengaruh temperatur injeksi molding dalam pembuatan MFC dari bahan PP-PET, M. Yousfi et.al (2012) telah membuat MFC dari PET/PE dengan menambahkan nano filler, Ljerka Kratofil et.al (2014) juga telah mempelajari efek masterbatch dalam campuran PET/HDPE serta Yin Chun Dong et.al (2017) meneliti pengaruh rasio penarikan komposit dari PP/PET dengan kompatibilizer PP-g-(DAP-co-GMA).

Pada penelitian ini untuk melihat pembentukan mikrofibril PET dalam pembuatan komposit PET/HDPE karena pengaruh temperatur dan rasio kecepatan penarikan dalam proses produksinya. Di samping itu akan dipelajari sifat mikro morfologi campuran PET/HDPE dengan adanya proses perlakuan penarikan dingin (cold drawing).

\section{METODE PENELITIAN}

\section{Material dan Peralatan yang digunakan}

Bahan-bahan yang digunakan dalam penelitian ini adalah resin HDPE tipe Titanvene HD 6070EA dari PT. Lotte Chemical Titan Nusantara dan PET tipe SKY PET BL-8050 produksi SK Keris. Adapun alat yang digunakan dalam penelitian ini antara lain : mesin ekstruder co-rotating twin screw merek Collin tipe ZK 25Ex36L/D dan alat Injection Molding merek Battenfeld dengan panjang screw $54 \mathrm{~cm}(\mathrm{~L} / \mathrm{D}=18)$.

\section{Cara Kerja}

PET sebelum digunakan dipanaskan terlebih dahulu dalam oven pada suhu $100^{\circ} \mathrm{C}$ selama $12 \mathrm{jam}$ dan setelah itu dicampurkan dengan HDPE menggunakan alat mesin ekstruder co-rotating twin-screw merek Collin dengan program pemanasan $170^{\circ} \mathrm{C} ; 240^{\circ} \mathrm{C} ; 265^{\circ} \mathrm{C}$ dan $280^{\circ} \mathrm{C}$ pada kecepatan putaran mesin $40 \mathrm{rpm}$. Komposisi material yang digunakan dalam penelitian ini adalah $85 \%$ (berat) HDPE dan $15 \%$ (berat) PET. Kondisi parameter kecepatan rasio penarikan dan temperatur cool drawing dapat dilihat pada tabel berikut :

TABEL 1. Parameter kondisi pembuatan komposit PET/HDPE

\begin{tabular}{ccc}
\hline Sampel Kode & $\begin{array}{c}\text { Rasio } \\
\text { Kecepatan } \\
\text { Penarikan }\end{array}$ & $\begin{array}{c}\text { Temperatur } \\
\text { Penarikan }\left({ }^{\mathbf{0}} \mathbf{C}\right)\end{array}$ \\
\hline \multirow{3}{*}{ A } & 2 & 75 \\
& & 80 \\
B & \multirow{2}{*}{3} & 85 \\
\hline \multirow{2}{*}{ C } & & 75 \\
& & 80 \\
& \multirow{2}{*}{4} & 85 \\
\hline \multirow{2}{*}{ D } & & 75 \\
& & 80 \\
& \multirow{2}{*}{5} & 85 \\
\hline
\end{tabular}




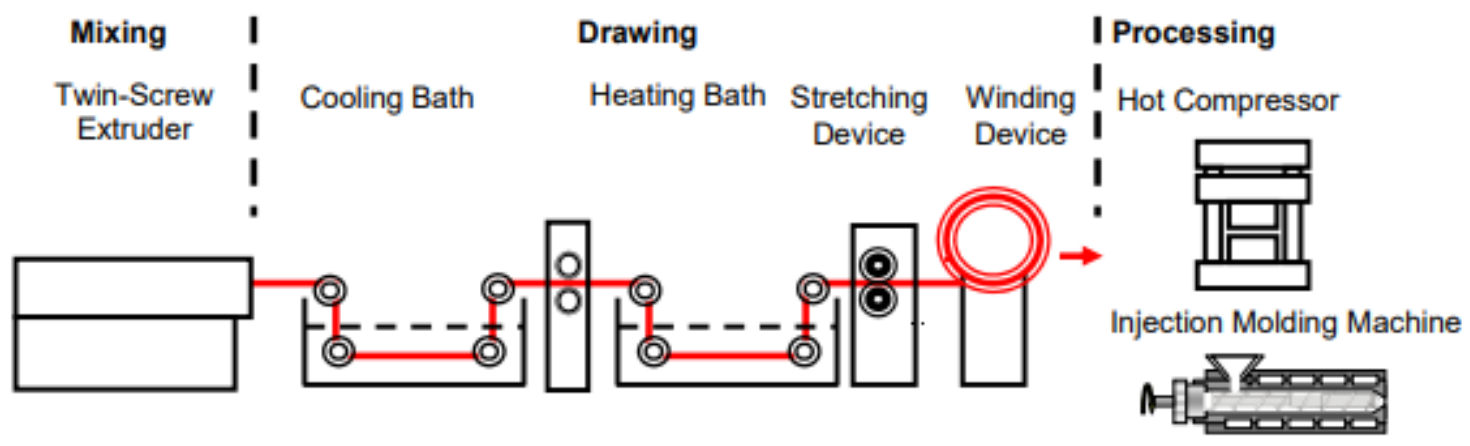

GAMBAR 2. Skema peralatan pembuatan komposit mikrofibril PET/HDPE

\section{Karakterisasi}

Sampel komposit PET/HDPE dalam bentuk pelet hasil ekstrusi yang telah dikeringkan, dimasukkan dalam alat injection molding dengan setting parameter suhu $185^{\circ} \mathrm{C}, 190^{\circ} \mathrm{C}, 195^{\circ} \mathrm{C}$ dan $200^{\circ} \mathrm{C}$. Hasil spesimen uji dogbone digunakan untuk pengujian mekanik kekuatan tarik dan kekuatan impak serta uji morfologi menggunakan alat SEM. Kondisi pengujian SEM dilakukan setelah sampel hasil spesimen dogbone direndam dalam solven xylene pada suhu $130^{\circ} \mathrm{C}$ selama 3 jam.

\section{HASIL DAN PEMBAHASAN}

\section{Karakterisasi Kekuatan Mekanik}

Pengukuran kekuatan merupakan salah satu indikasi terpenting dari kekuatan suatu material dan sifat yang paling banyak ditentukan dari bahan material komposit. Uji tensile adalah pengukuran kemampuan material untuk menahan gaya dari tarikan untuk menentukan sejauh mana materi mengalami peregangan sebelum putus. Berbagai jenis bahan plastik sering dibandingkan berdasarkan kekuatan tarik, elongasi, dan data modulus tarik. Pengujian dalam penelitian ini meliputi pengujian kekuatan tarik (tensile strength), tensile modulus (E modulus), elongasi dan kekuatan impak (impact strength).

TABEL 2. Hasil Pengujian Sifat Mekanik sampel komposit PET/HDPE

\begin{tabular}{|c|c|c|c|c|}
\hline $\begin{array}{c}\text { Sampel } \\
\text { Kode }\end{array}$ & $\begin{array}{l}\text { Rasio Kecepatan } \\
\text { Penarikan }\end{array}$ & $\begin{array}{c}\text { Temperatur } \\
\text { Penarikan }\left({ }^{\circ} \mathrm{C}\right)\end{array}$ & $\begin{array}{l}\text { Kekuatan Tarik } \\
\text { (MPa) }\end{array}$ & $\begin{array}{c}\text { Kekuatan Impak } \\
\left(\mathrm{kJ} / \mathrm{m}^{2}\right)\end{array}$ \\
\hline \multirow{3}{*}{ A } & \multirow{3}{*}{2} & 75 & 22,05 & 109,18 \\
\hline & & 80 & 23,71 & 114,59 \\
\hline & & 85 & 24,60 & 96,40 \\
\hline \multirow{3}{*}{ B } & \multirow{3}{*}{3} & 75 & 21,58 & 89,34 \\
\hline & & 80 & 22,90 & 72,37 \\
\hline & & 85 & 24,02 & 47,59 \\
\hline \multirow{3}{*}{$\mathrm{C}$} & \multirow{3}{*}{4} & 75 & 21,44 & 120,18 \\
\hline & & 80 & 22,72 & 131,49 \\
\hline & & 85 & 24,13 & 71,46 \\
\hline \multirow{3}{*}{$\mathrm{D}$} & \multirow{3}{*}{5} & 75 & 21,92 & 118,94 \\
\hline & & 80 & 23,08 & 110,40 \\
\hline & & 85 & 24,00 & 45,89 \\
\hline HDPE & - & - & 21,03 & 146,84 \\
\hline PET & - & - & 53,07 & 77,53 \\
\hline
\end{tabular}


Dari data TABEL 2 terlihat secara umum bahwa pembuatan komposit PET/HDPE mempunyai kekuatan tarik sedikit lebih besar bila dibandingkan dengan kekuatan tarik sampel HDPE murni sebagai matriksnya, tetapi lebih rendah dari kekuatan tarik PET murni. Kekuatan tarik terbesar dari komposit PET/HDPE adalah 24,60 MPa pada kondisi rasio kecepatan penarikan 2 dan temperatur $85^{\circ} \mathrm{C}$. Hal ini dapat dilihat pada GAMBAR 3 bahwa pada rasio penarikan yang sama dalam proses pembuatan komposit mikrofibril PET/HDPE pada berbagai variasi temperatur panarikan menunjukkan kekuatan mekanik untuk tensile strength metode A (rasio kecepatan penarikan 2) mempunyai nilai tertinggi.

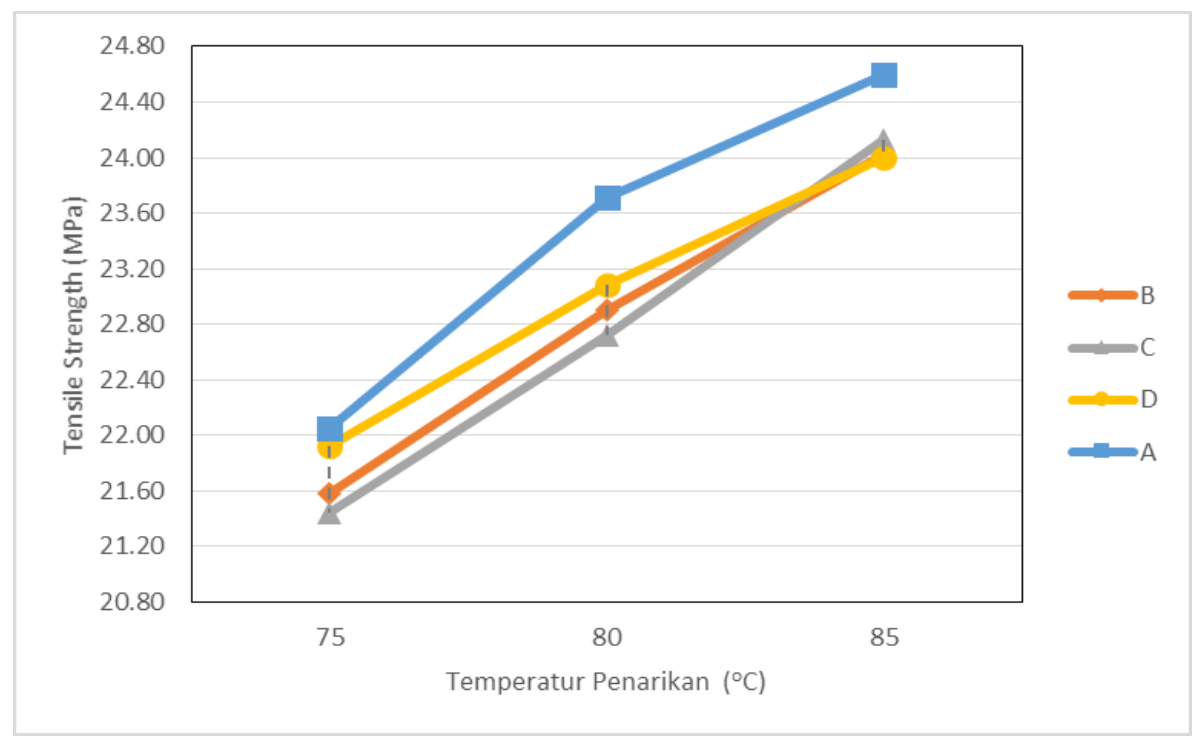

GAMBAR 3. Pengaruh temperatur penarikan terhadap kekuatan tarik pembuatan komposit mikrofibril PET/HDPE pada kondisi rasio kecepatan penarikan yang sama.

GAMBAR 3 juga menunjukkan semakin tinggi rasio kecepatan penarikan proses juga meningkatkan nilai kekuatan tarik pada pembuatan komposit PET/HDPE. Kekuatan mekanik untuk tensile strength pada pembuatan komposit mikrofibril PET/HDPE meningkat sedikit bila dibandingan dengan kekuatan tarik HDPE murni. Hal ini dimungkinkan karena campuran PET/HDPE tidak tercampur secara kompatibel karena campuran antara PET yang bersifat polar dan HDPE bersifat non polar tidak dapat bercampur secara homogen. Inilah yang mengakibatkan kekuatan mekanik yang dihasilkan tidak mengalami kenaikan secara signifikan. Sistem campuran antara matriks (polietilena) dan fiber PET yang tidak kompatibel dapat ditunjukan pada foto SEM di bawah ini.

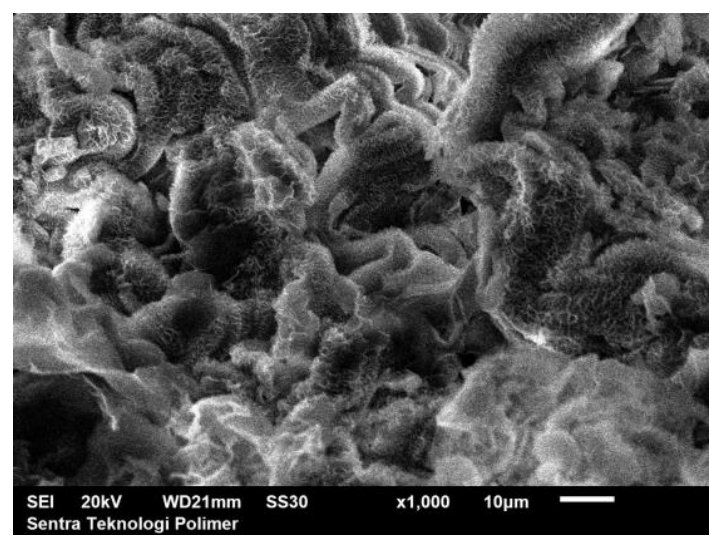

(a)

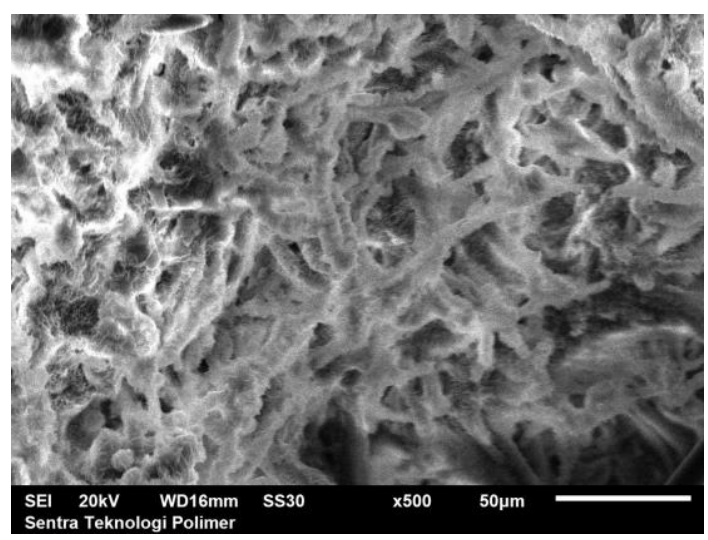

(b)

GAMBAR 4. Foto SEM interaksi antara matriks (PE) dengan fiber PET yang tidak kompatibel pada sampel kondisi temperatur penarikan $75^{\circ} \mathrm{C}$ rasio kecepatan penarikan 2 (a) dan kondisi temperatur penarikan $85^{\circ} \mathrm{C}$ rasio kecepatan penarikan $5(\mathrm{~b})$ 
Sifat impak dari bahan polimer secara langsung berkaitan dengan ketangguhan material. Ketangguhan (toughness) didefinisikan sebagai kemampuan polimer untuk menyerap energi yang tersalurkan. Luas area di bawah kurva stress-strain berbanding lurus dengan ketangguhan dari suatu material. Energi impak adalah ukuran ketangguhan. Semakin tinggi energi impak material, semakin tinggi ketangguhan dan sebaliknya. Hasil pengujian kekuatan impak secara keseluruhan disajikan dalam GAMBAR 5.

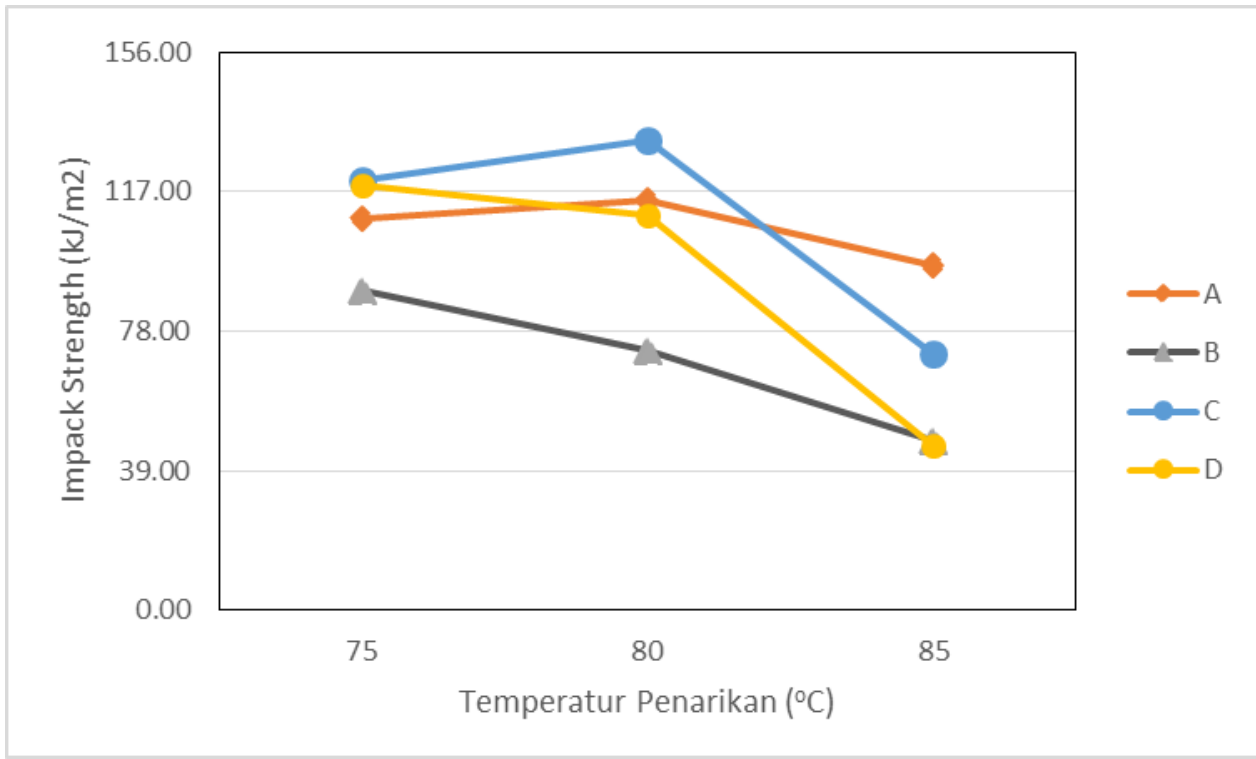

GAMBAR 5. Pengaruh temperatur penarikan terhadap kekuatan impak pembuatan komposit mikrofibril PET/HDPE pada kondisi rasio kecepatan penarikan yang sama.

Dari grafik di atas kekuatan impak terlihat bahwa semakin tinggi temperatur proses penarikan dingin (cold drawing) pembuatan komposit PET/HDPE menyebabkan turunnya kekuatan impak. Fenomena ini dijelaskan dalam pembahasan hubungan antara E-modulus dengan sifat kuat tarik, dimana semakin tinggi E-modulus suatu material semakin kaku dan berakibat pada menurunnya sifat impak suatu material.

Adapun pengaruh rasio kecepatan penarikan pada pembuatan komposit mikrofibril PET/HDPE umumnya mengalami penurunan kekuatan tarik pada temperatur proses penarikan yang sama. Sedang kekuatan impaknya tidak menunjukkan adanya kecenderungan mengalami kenaikan atau penurunan (lihat GAMBAR 6).

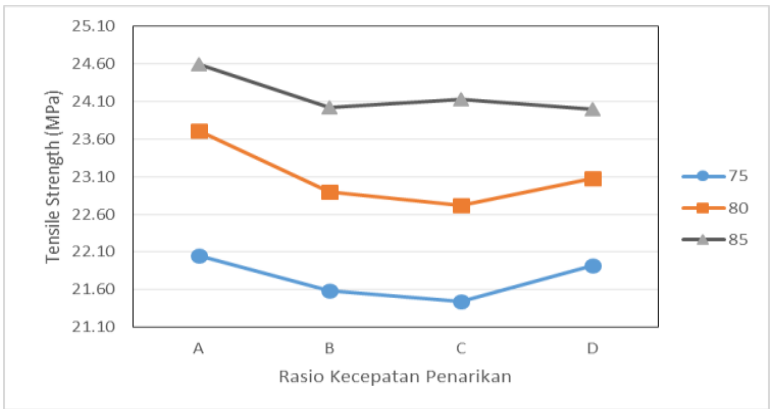

(a)

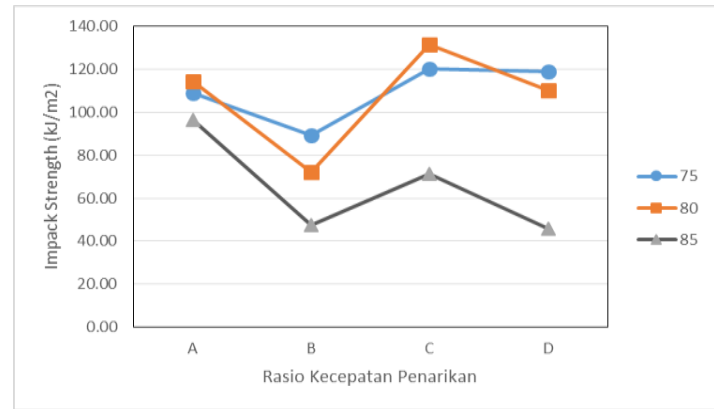

(b)

GAMBAR 6. Pengaruh rasio kecepatan penarikan terhadap kekuatan tarik (a) dan kekuatan impak (b) pada pembuatan komposit mikrofibril PET/HDPE pada kondisi temperatur penarikan yang sama. 


\section{Analisa Morfologi Komposit Mikrofibril PET/HDPE}

Hasil pengamatan sifat morfologi pada pembuatan komposit mikrofibril PET/HDPE dengan variasi rasio kecepatan penarikan dapat dilihat pada GAMBAR 7-9. Pada GAMBAR 7 menunjukkan terbentuknya fiber PET dengan jumlah yang masih sedikit sehingga fungsi fiber PET sebagai penguat dalam struktur komposit belum optimal. Hal ini berakibat pada kekuatan mekanik yang dihasilkan pada pembuatan komposit PET/HDPE masih rendah, hanya meningkat lebih sedikit dari kekuatan tarik HDPE murninya.

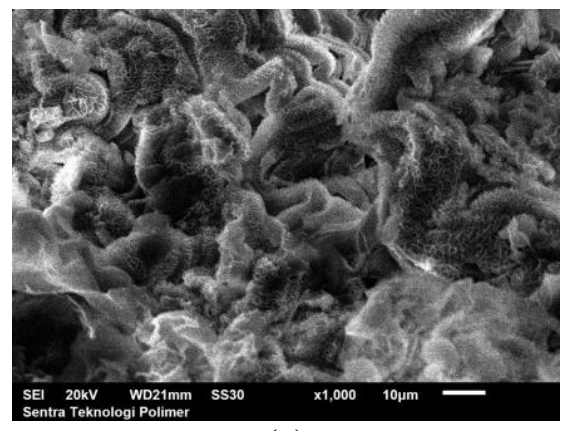

(a)

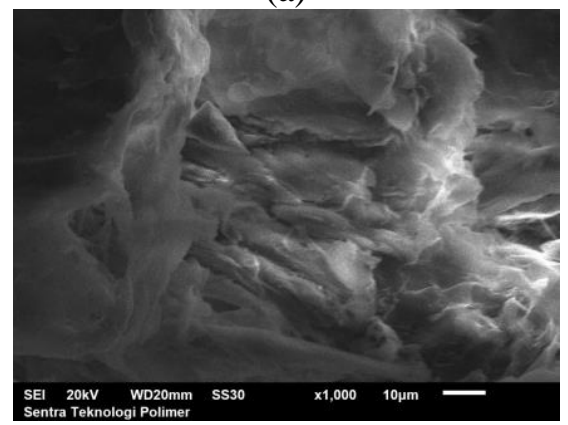

(c)

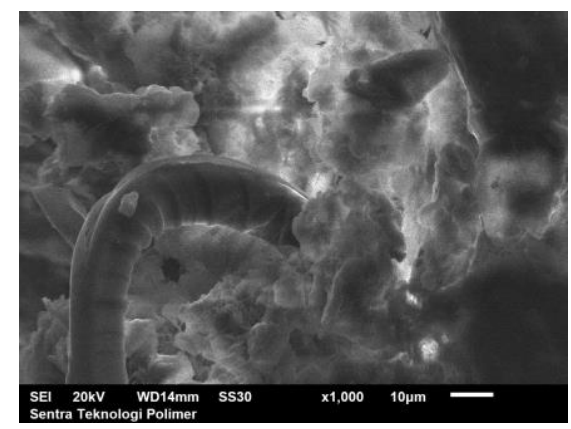

(b)

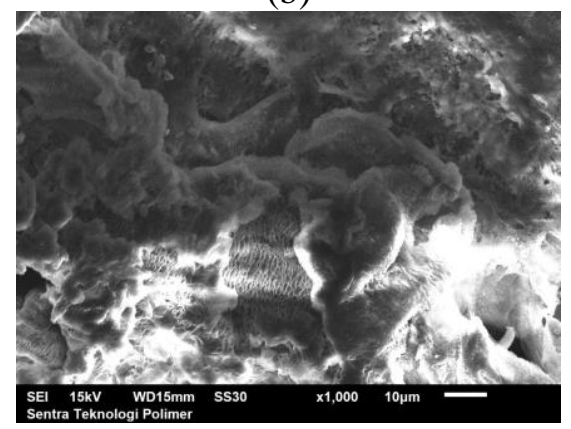

(d)

GAMBAR 7. Foto SEM sampel komposit PET/HDPE pada kondisi temperatur penarikan $75^{\circ} \mathrm{C}$ untuk spesimen uji

dogbone setelah direndam dalam xylene pada suhu $130^{\circ} \mathrm{C}$ selama 3 jam dengan perbesaran $1000 \mathrm{x}$ : (a) Sampel rasio kecepatan penarikan 2 (b) Sampel rasio kecepatan penarikan 3, (c) Sampel rasio kecepatan penarikan 4 \& (d) Sampel rasio kecepatan penarikan 5.

Adapun untuk sampel komposit PET/HDPE pada temperatur penarikan $85^{\circ} \mathrm{C}$, fiber PET yang dihasilkan juga masih sedikit. GAMBAR 8.c memperlihatkan PET dalam campurannya belum terbentuk fiber tetapi masih dalam bentuk drop (butiran-butiran) kecil calon pembentuk fiber. Hal ini bisa jadi disebabkan kurangnya penarikan pada proses cold drawing atau jenis bahan baku PET yang kurang sesuai dengan spesifikasi untuk fiber. Akibatnya pembentukan fiber yang jumlahnya sedikit dalam pembuatan komposit mikrofibril PET/HDPE menyebabkan secara umum kekuatan mekanik komposit tidak secara signifikan bertambah.

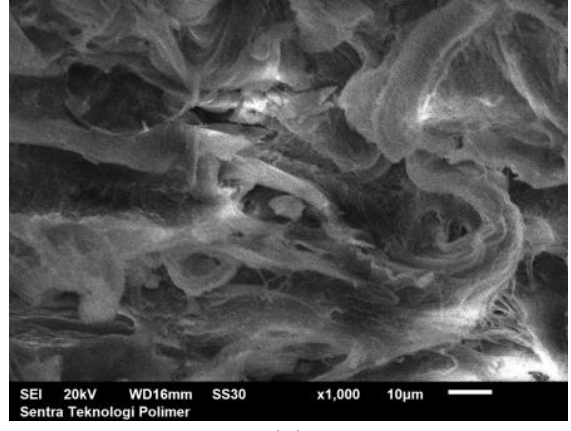

(a)

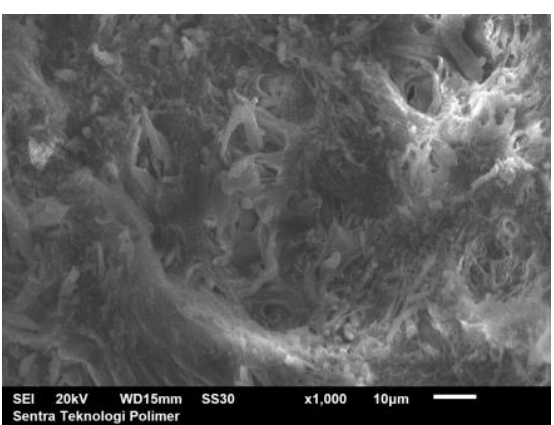

(b) 


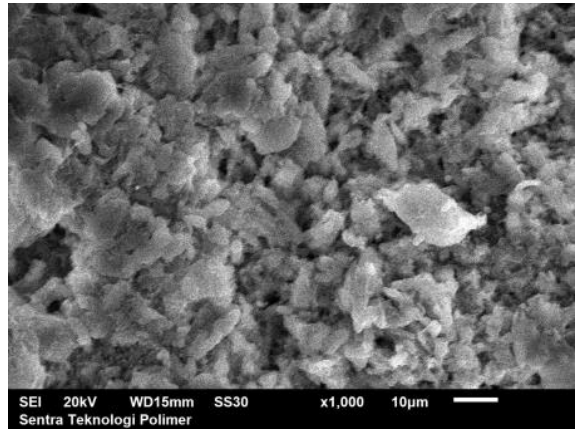

(c)

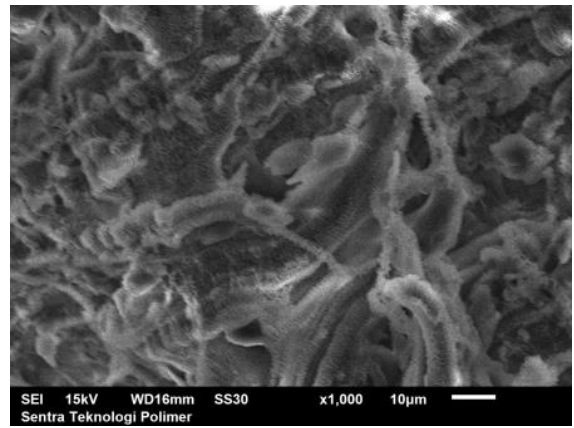

(d)

GAMBAR 8. Foto SEM sampel komposit PET/HDPE pada kondisi temperatur penarikan $80^{\circ} \mathrm{C}$ untuk spesimen uji dogbone setelah direndam dalam xylene pada suhu $130^{\circ} \mathrm{C}$ selama 3 jam dengan perbesaran $1000 \mathrm{x}$ : (a) Sampel rasio kecepatan penarikan 2 (b) Sampel rasio kecepatan penarikan 3, (c) Sampel rasio kecepatan penarikan 4 \& (d) Sampel rasio kecepatan penarikan 5.

Secara umum GAMBAR 9 memperlihatkan fiber PET dalam struktur campuran dengan matrik PE yang masih sedikit, belum menunjukkan terbentuknya fiber PET sesuai dengan yang diharapkan dalam penelitian ini. Seharusnya dalam penelitian ini dihasilkan fiber PET yang banyak sebagai penguat struktur kompositnya sehingga kekuatan mekanik terutama sifat tarik meningkat. Untuk itu dalam penelitian selanjutnya perlu dipertimbangkan bahan baku PET yang dipakai harus grade fiber sehingga pembentukan fiber lebih mudah dalam proses penarikan kompositnya.

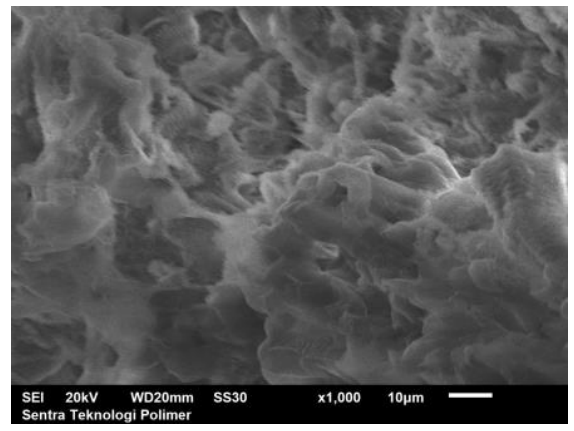

(a)

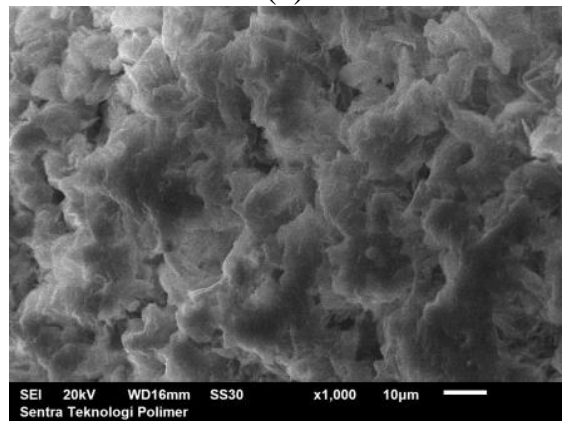

(c)

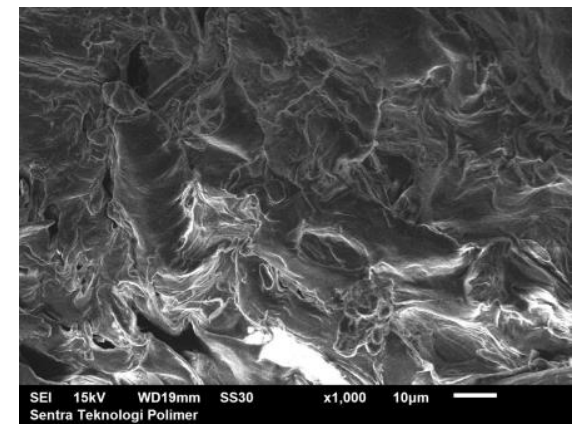

(b)

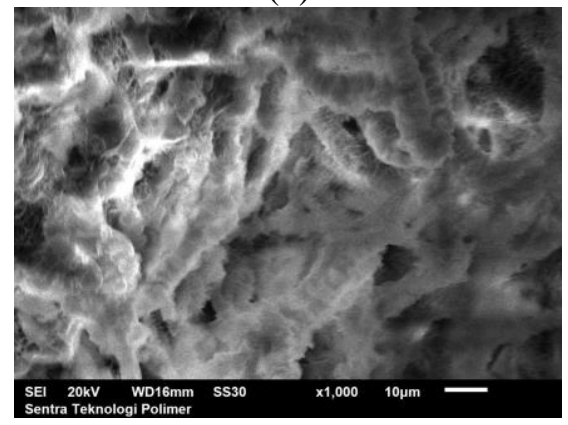

(d)

GAMBAR 9. Foto SEM sampel komposit PET/HDPE pada kondisi temperatur penarikan $85^{\circ} \mathrm{C}$ untuk spesimen uji

dogbone setelah direndam dalam xylene pada suhu $130^{\circ} \mathrm{C}$ selama 3 jam dengan perbesaran $1000 \mathrm{x}$ : (a) Sampel rasio kecepatan penarikan 2 (b) Sampel rasio kecepatan penarikan 3, (c) Sampel rasio kecepatan penarikan 4 \& (d) Sampel rasio kecepatan penarikan 5 . 


\section{SIMPULAN}

Pembuatan komposit mikrofibril PET/HDPE telah dilakukan dengan mempelajari pengaruh temperatur penarikan dan rasio kecepatan penarikan pada proses cold drawing. Temperatur penarikan mempunyai pengaruh yang signifikan yaitu semakin tinggi temperatur yang digunakan semakin besar nilai sifat kuat tariknya walaupun komposit yang dihasilkan belum mampu menaikkan sifat mekaniknya secara signifikan dibandingkan dengan sifat kuat tarik polimer HDPE murni. Pengaruh rasio kecepatan penarikan dalam proses cold drawing dalam penelitian ini semakin besar rasio kecepatan mengakibatkan penurunan sifak mekanik baik kuat tarik maupun kekuatan impak.

Hasil analisa morfologi menggunakan SEM menunjukkan fiber PET yang terbentuk dalam campuran kompositnya masih sedikit dan interaksi antara matriks PE dan penguat PET belum mempunyai ikatan yang solid. Hal inilah yang menyebabkan kekuatan mekanik secara umum dari komposit ini belum menunjukkan kenaikan yang signifikan.

\section{REFERENSI}

[1] Yin Chun Dong, Jian Ping Xu, and Shen Fan, "The effect of draw ratio on the properties PP/PET blends compatibilised by PP-g-(DAP-co-GMA)", in Journal of Plastics, Rubber and Composites, 2017, Vol. 46, No. 9, pp. 396-404.

[2] Maja Kuzmanovic, Laurens Delva, Ludwig Cardon and Kim Ragaert, "Morphology and mechanical properties of PP/PET blends and microfibrillar composites", in Polymers Journal, 2016, Vol,8, No. 355, pp.1-16.

[3] Ljerka Kratofil Kehula, Zlata Hmjak-Murgic, and Jasenka Jelencic, "Study of masterbatch effect on miscibility and morphology in PET/HDPE blends", in Journal of Adhesion Science and Technology, 2015, Vol. 29, No. 2, pp. 74-93.

[4] J. Narang, N. Chauhan, A. Singh, and C.S. Pundir, "A Nylon Membrane Based Amperometric Biosensorbfor Polyphenol Determination," in Journal of Molecular Catalysis B: Enzymatic, 2011, vol. 72, pp. 276-281..

[5] Karingamanna Jayanarayanan, Archana Ravichandran, Dhivya Rajendran, Monikumar S, Abirami V, Sabu Thomas and Kuruvilla J, "Morphology and mechanical of normal blends and in-situ microfibillar composites from low-density polyethylene and poly (ethylene terephthalate)", in Polymer Plastics Technology and Engineering, 2010, vol. 49, pp. 442-448.

[6] Karingamanna Jayanarayanan, Tomlal Jose, Sabu Thomas and Kuruvilla Joseph, "Effect of draw ratio on the microstructure, thermal, tensile and dynamic rheological properties of insitu microfibrillar composites", in European Polymer Journal, 2009, Vol. 45, No. 6, pp. 1738-1747.

[7] Hong Sheng Xu, Zhong Ming Li, "Rheological Behavior Comparation Between PET/HDPE and PC/HDP Microfibillar Blends", in Polymer Engineering and Science, 2005, Vol. 45, pp. 1231-1238.

[8] Yong Lei, Qinglin Wu, Quanguo Zhang, "Morphology and properties of microfibrillar composites based on recycled poly (ethylene terephthalate) and high density polyethylene" in Composites : Part A, 2009, No.40, pp. 904-912.

[9] L. Fasce, R. Seltzer, P. Frontini, "Mechanical and Fracture Characterization of 50:50 HDPE/PET blends presenting different phase morphologies" in Polymer Engineering and Science, 2005, No. 45, pp. 354-363.

[10] Xiang Bin Xu, Zhong Ming Li, Run Ze Yu, Ai Lu, Ming Bo Yang \& Rui Huang, "Formation of in situ CB/PET microfibers in CB/PET/PE Composites by slit die 
extrusion and hot stretching" in Macromolecular Materials and Engineering, 2004, No. 289 , pp. 568-575. 